\title{
PERMISSIBLE VOLTAGE ASYMMETRY FOR ASYNCHRONOUS MOTOR OPERATING IN NON-NOMINAL OPERATING CONDITIONS
}

\author{
Victor Petko, Aleksey Petrov, Ilmira Rakhimzhanova, Vladimir Shakhov, Yuriy Ushakov, Maxim Fomin \\ Orenburg State Agrarian University, Russia \\ srvg1982@rambler.ru,pas056@mail.ru, ahmetova_i@mail.ru, shahov-v@yandex.ru, \\ 1u6j1a159@mail.ru,mbfom@mail.ru
}

\begin{abstract}
The article is devoted to the development of methods for theoretical substantiation of the permissible supply voltage asymmetry coefficient for an asynchronous electric motor operating in the steady state under nonnominal operating conditions. The core of the technique lies in the fact that the heat loss power of the electric motor operating in the steady state with the actual: load/utilization level, asymmetry degree, supply voltage is calculated. The calculation is carried out using an L-shaped equivalent circuit of the electric motor, which is connected separately to the voltage components of the forward and inverse phase sequences with the subsequent imposition of the calculation results produced by the algorithm proposed by the authors and developed on the basis of the program in the MathCAD system for each of the components. Provided that we predetermine the motor torque under voltage $u$, the degree of asymmetry of voltage $k$ and angular velocity $\omega-M(u, k, \omega)$; the moment of resistance as a function of degree of load $z$ and angular velocity $\omega-M_{\mathrm{c}}(z, \omega)$; and the steady angle speed $\omega_{y}(z, k)$ by numerically solving the equation $M(u, k, \omega)-M_{\mathrm{c}}(z, \omega)=0$. Then, we find the power of heat loss $\Delta P_{\mathrm{y}}(u, z, k)$ for this angular velocity. The permissible asymmetry of the voltage $k_{d}(u, z, t)$ is determined by equating these losses to losses permissible under heating conditions, which are a function of the temperature $t$ of the ambient temperature $\Delta P_{d}(t)$, and solving the resulting equation for the asymmetry factor of the supply voltage. As an example, we made the calculation of the parameters of the steady state of the 4A355S6U3 electric motor. According to the calculation results, the curves of the dependence of the power of heat losses on the magnitude and degree of voltage asymmetry at different values of the motor utilization/load rate were plotted. An acceptable voltage asymmetry factor is determined for these conditions.
\end{abstract}

Keywords: permissible voltage asymmetry, asynchronous motor, asymmetry coefficient, reverse phase sequence, degree of loading.

\section{Introduction}

There is a high probability of the supply voltage asymmetry in power supply systems. Its reasons are: uneven load distribution in phases; open or wire overlapping; contact violation in the switching equipment. The supply voltage asymmetry and its extreme case - phase failure is one of the common causes of damage in three-phase motors [1;2]. The works of I.I. Martynenko, E.G. Kurenogo and many others are devoted to the determination of the acceptable level of the voltage asymmetry supplying asynchronous electric motors, under nominal operating conditions [3;4].

However, in the vast majority of cases, electric motors operate at supply voltage [5], ambient temperature, and load degree different from the nominal values. In this case, overheating of the electric motor in the steady state will be observed at various asymmetry degrees of the net voltage. To this value the setting of protection against voltage asymmetry should be adjusted in order to eliminate its "false" operation, when the asymmetry has not yet reached a value acceptable for the given operating conditions, and at the same time to prevent the failure of protection, when the asymmetry exceeds the value allowed by the heating condition. This work is devoted to determining the permissible level of voltage asymmetry at the input terminals of an electric motor operating in nonnominal operating conditions.

\section{Materials and methods}

Voltage asymmetry is a phenomenon, in which the phase voltage amplitudes and / or angles between them are not equal to each other. Meanwhile, any asymmetric system of stresses can be decomposed into symmetrical components of the forward, reverse, and zero phase sequences (Fig. 1). Moreover, the degree of voltage asymmetry is estimated by the complex asymmetry coefficients $k_{\mathrm{A}}=U_{2} / U_{1}$ and unbalance $k_{\mathrm{n}}=U_{0} / U_{1}$, where $U_{1}, U_{2}$ and $U_{0}$ are the components of the direct, reverse and zero phase sequences, respectively, which uniquely determine it. Since the stator windings of an asynchronous electric motor are not connected to the neutral wire of the power supply network [6; 7], the voltage of the zero sequence does not affect the operating parameters of the electric motor and can be ignored. In this case, we can assume that each of the phase voltages is the sum of the symmetrical 
components of the forward and reverse phase sequences and the asymmetry of this voltage is completely characterized only by the asymmetry coefficient. In this regard, devices have been developed $[8,9,10]$ for protecting electric motors that respond precisely to the asymmetry coefficient. To simplify the mathematical records, in the future we will denote it by the letter symbol $k[16]$.

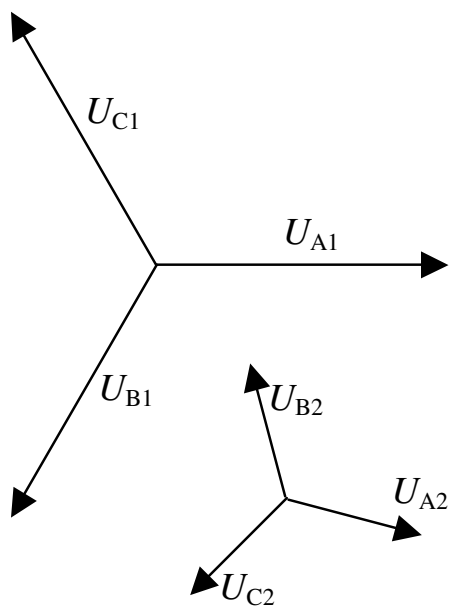

a)

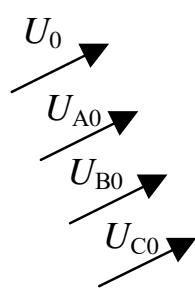

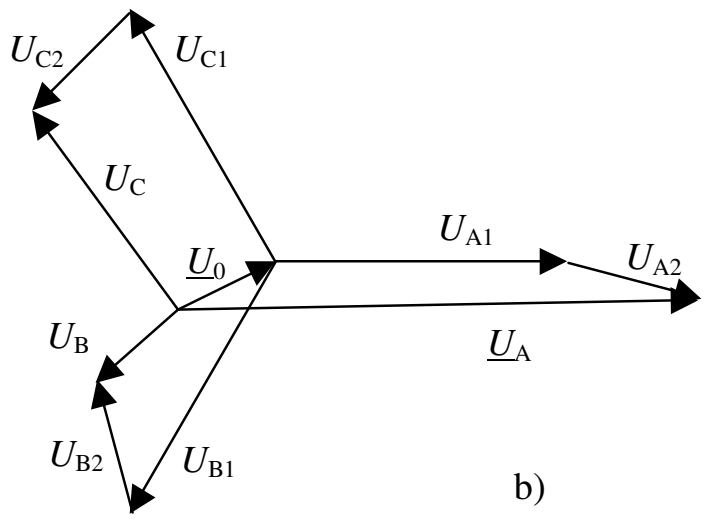

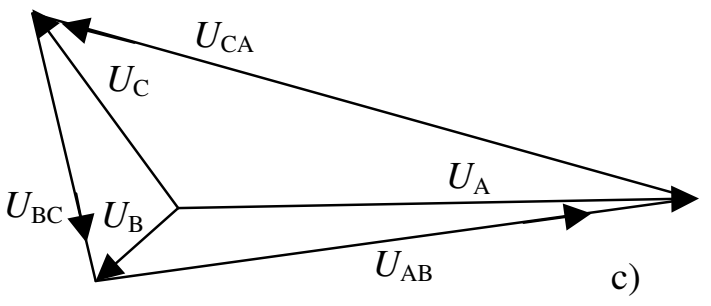

Fig. 1. Vector diagrams of voltages: a - components: direct $U_{\mathrm{A} 1}, U_{\mathrm{B} 1}, U_{\mathrm{C} 1}$, reverse $U_{\mathrm{A} 2}, U_{\mathrm{B} 2}, U_{\mathrm{C} 2}$ and zero $U_{0}=U_{\mathrm{A} 0}=U_{\mathrm{B} 0}=U_{\mathrm{C} 0}$ phase sequences; b - phase voltage asymmetric system $U_{\mathrm{A}}, U_{\mathrm{B}}, U_{\mathrm{C}}$; $\mathrm{c}$ - interfacial (linear) voltages $U_{\mathrm{CA}}, U_{\mathrm{BC}}, U_{\mathrm{AB}}$.

At the same time, it was shown in [11] that the phase shift between the voltages of the forward and reverse sequences affects only the current redistribution along the motor windings, but does not affect its power and energy characteristics. Therefore, it is advisable to determine the acceptable level of voltage asymmetry from the point of mathematical expression simplification, provided that the stresses initial phases of the forward and reverse sequences coincide and are equal to zero. In this case, the asymmetry degree can be adequately estimated by the module of the asymmetry coefficient $k_{A}=k=U 2 / U 1$.

In [11], in order to quantify the influence degree of the asymmetry of the supply voltage on the electric motor operating parameters at a given value, the currents, powers, and moments were calculated as a function of the angular velocity of the motor shaft. In continuation of this work, the energy parameters of an electric motor operating in steady state for a particular type of working machine were determined in [12]. In this case, the parameters were determined not only as a function of the asymmetry coefficient, but also as a function of the loading degree, the steady angular velocity and the level of the symmetrical voltage component of the direct phase sequence. The calculation was carried out using the L-shaped equivalent circuit (Fig. 2) by connecting it separately to the components of the forward and reverse phase sequences, followed by summing the calculation results for each of the components [11].

It was taken into account that, since the magnetic fields generated by the currents of the forward and reverse phase sequences rotate in mutually opposite directions $\left(\omega_{01}=-\omega_{02}\right)$, and the rotor rotates with an angular velocity $\omega$ ), the rotor slips relative to these fields are in the ratio

$$
s_{2}=2-s_{1} \text {. }
$$

Considering this resistance, $r_{1 M}$ " and $r_{2 M}$ " were determined by the formulas

$$
r_{M 1}{ }^{\prime \prime}=r_{2}{ }^{\prime \prime} \omega /\left(\omega_{01}-\omega\right) \text { and } r_{M 2}{ }^{\prime \prime}=-r_{2}{ }^{\prime \prime} \omega /\left(\omega_{01}+\omega\right) \text {. }
$$




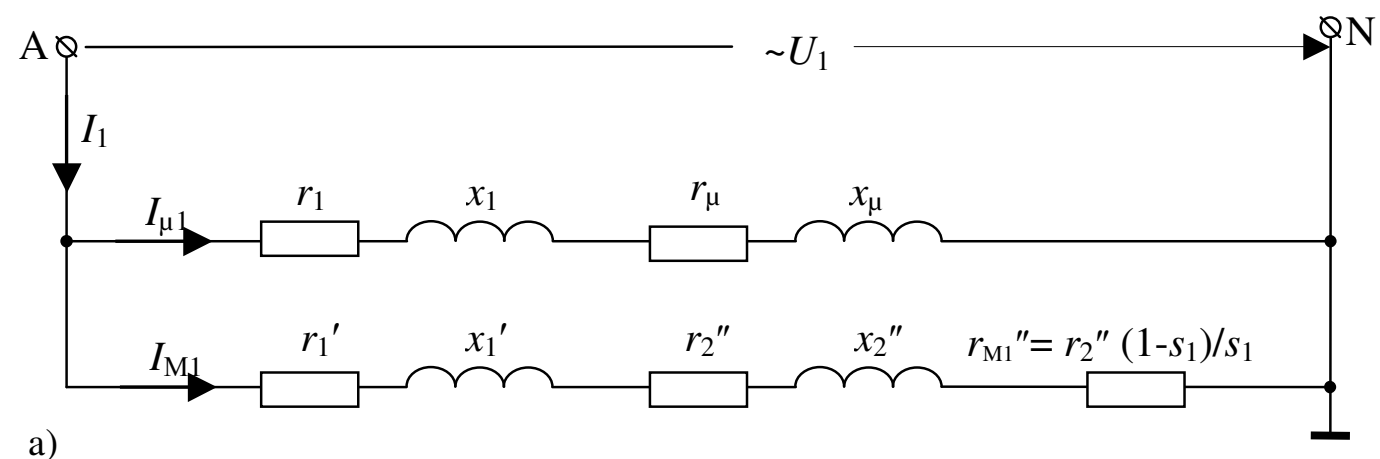

a)

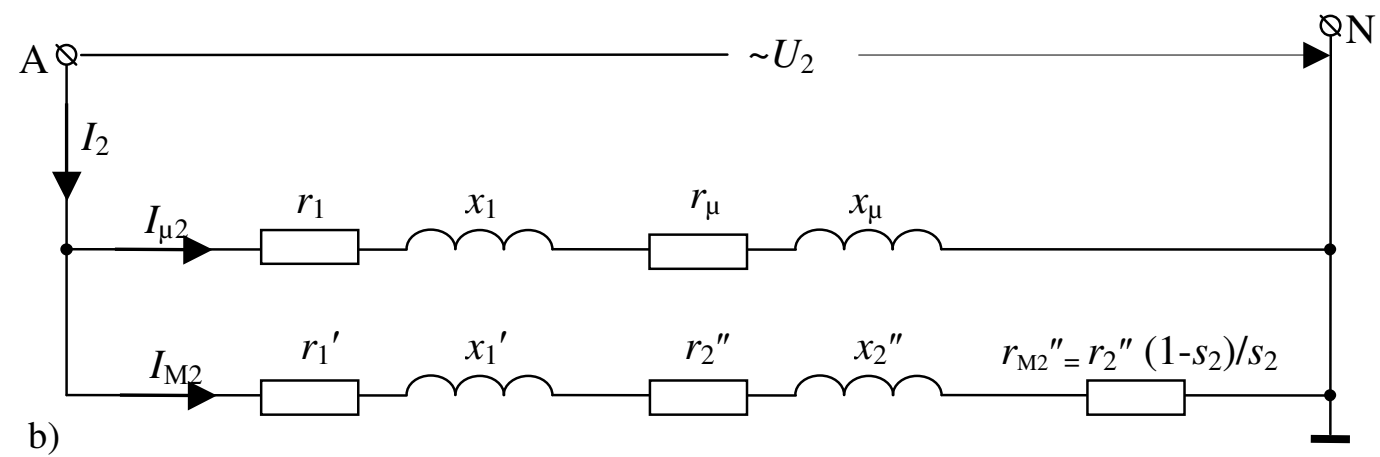

Fig. 2. Phase A equivalent circuit of an asynchronous electric motor connected to symmetrical voltages of the forward $(a)$ and reverse $(b)$ phase sequences: $r_{1}, x_{1}$ - active and reactive resistance of the stator winding with a T- shaped equivalent circuit, $\Omega ; r_{1}{ }^{\prime}, x_{1}{ }^{\prime}-$ adjusted active and reactive resistance of the stator winding on the $\mathrm{L}-$ shaped equivalent circuit, $\Omega ; r_{2}{ }^{\prime \prime}, x_{2}{ }^{\prime \prime}-$ active and reactive resistance of the rotor winding, reduced to the stator winding, corrected for the L-shaped equivalent circuit, $\Omega ; r_{\mu}$ and $x_{\mu}$ - active and reactive resistance of the magnetization circuit, $\Omega ; r_{M 1}{ }^{\prime \prime}$ and $r_{M 2}{ }^{\prime \prime}-$ active resistance in the rotor circuit, the developed electric power, which simulates the mechanical power on the shaft, $\Omega ; s_{1}=\left(\omega_{01}-\omega\right) / \omega_{0}$ and $s_{2}=\left(\omega_{02}-\omega\right) / \omega_{0}$ - rotor slip relative to the stator magnetic

field, respectively, with respect to the forward and reverse rotation field; $\omega_{01}, \omega_{02}$ and $\omega$ - synchronous angular velocity of rotation of the stator magnetic field in the forward and reverse directions and the angular velocity of rotation of the rotor, $\mathrm{s}^{-1}$, respectively

However, in order to determine the allowable asymmetry degree of the supply voltage, it is not enough to know the steady-state heat dissipation power of an electric motor operating under nonnominal operating conditions determined in [12]. It must be compared with the heat dissipation capacity admissible under real cooling conditions. The heat dissipation power (heat loss power) in the nominal mode is determined by the formula

$$
\Delta P_{n=} P_{n}\left(1-\eta_{n}\right) / \eta_{n}
$$

where $P_{n}$ - power on the motor shaft in nominal mode, $\mathrm{W}$;

$\eta_{n}$ - efficiency in nominal mode.

Then the permissible heat loss power as a function of the ambient temperature $t$, different from the calculated temperature $t_{P}$, equal to $+40^{\circ} \mathrm{C}[13 ; 14]$

$$
\Delta P_{d}(t)=\Delta P_{n}\left(T_{d}-t\right) /\left(T_{d}-40\right),
$$

where $T_{d}$-permissible temperature for the insulation class of the motor windings, ${ }^{\circ} \mathrm{C}$.

Further, by the method described in [12], the heat loss power in the steady state $\Delta P_{\mathrm{y}}(u, z, k)$ is determined as a function of the symmetric component of the direct sequence voltage $u$, as well as the load factors of the electric motor $z$ and voltage asymmetry $k$. The asymmetry coefficient $k$, at which the heat dissipation power of the electric motor becomes equal to the permissible heat dissipation 
power for a given electric motor at a given ambient temperature, will be considered a permissible voltage asymmetry coefficient $k_{d}$

$$
\Delta P_{d}(t)-\Delta P_{\mathrm{y}}(u, z, k)=0
$$

Solving this equation with respect to $\mathrm{k}$, we obtain its allowable value $k_{d}(u, z, t)$ as a function of the symmetric component of the voltage of the direct sequence $u$, the load factor of the electric motor $z$, and the temperature of the ambient (cooling) medium $t$. This will allow to determine the value of the allowable asymmetry coefficient for any of the given values of the listed values. The setting of electric motor protection against voltage asymmetry should be oriented on it.

The algorithm for determining the allowable asymmetry coefficient and steady-state parameters is shown in Figure 3. The calculation according to the above algorithm of the allowable voltage asymmetry coefficient was performed in order to compare the results for the same 4A355S6U3 electric motor as in $[11 ; 12]$.

The calculation program was implemented in the mathematical environment MathCAD. Technical data of the electric motor $[15 ; 16]$ : nominal power $-P_{n}=160 \mathrm{~kW}$; nominal phase voltage $U_{n f}=220 \mathrm{~V}$; nominal rotation speed $-n_{n}=985 \mathrm{rpm}$; nominal efficiency $-\eta_{n}=0.935$; nominal power factor $-\cos \varphi_{n}=0.90$; multiplicity of the critical moment $-\mu_{k}=2.2$; resistance of the equivalent circuit in relative units (inductive resistance of the magnetization circuit $-Z_{\mu}=2.8$; updated stator resistance $-R_{1}{ }^{\prime}=0.023$; updated stator reactance $-X_{1}{ }^{\prime}=0.11$; specified active and reactive resistance of the rotor, reduced to the stator winding, $-R_{2}{ }^{\prime \prime}=0.016$ and $X_{2}{ }^{\prime \prime}=0.14$ ).

According to module 1 of the developed algorithm, the source catalog data of the electric motor, the parameters and the type of working machine mechanical characteristics, and the intended ranges of changes in the operating conditions: the voltage of the direct sequence $u$, the asymmetry coefficient $k$, the degree of loading $z$, and the ambient temperature $t$ were recorded in the computer memory. Next, we calculated the parameters of the equivalent circuit of the electric motor, independent of operating conditions (module 2).

Calculations made in accordance with modules 3-6 determine the parameters of the mechanical characteristics of the electric motor and the working machine, for which a machine with a fan characteristic is selected.

In this case, the dependences of the total current and currents in the main and magnetizing circuits, as well as the capacities in these elements on the rotation frequency at fixed values of voltage and its asymmetry coefficient, were also determined. Equating the moment of the electric motor to the moment of resistance and solving the obtained equation with respect to the angular velocity, we determined the steady-state angular velocity $\omega_{\mathrm{y}}(u, z, k)$ of the electric motor for specific values of voltage, load factor, and voltage asymmetry coefficient (module 7 ). For the same fixed values of the indicated values, the power losses $\Delta P_{\mathrm{y}}(u, z, k)$ of the electric motor operating in the steady state were also determined (module 8 ). Then, the dependences of the steady angular velocity and power losses on the voltage asymmetry coefficient are determined (modules $9 \ldots 11$ ).

The permissible asymmetry coefficient $k_{d}(u, z, t)$ is determined in accordance with equation (5) when executing module 12 of the algorithm. Since it is a function of the voltage of the direct phase sequence $u$, the degree of loading of the motor $z$ and the temperature of the cooling medium $t$, the modules 13-18 of the algorithm allow us to present these dependencies in the form of graphs and tables (module 19).

\section{Results and discussion}

Note, that In the graphs hereinafter, the physical quantities along the axes are plotted in units of the International SI System of Units.

The intermediate results of the calculations were:

1. The dependences of the moments of the working machine and electric motor on the angular velocity (mechanical characteristics) presented in the following figure (Fig. 4). For the rated mode of operation of the electric motor (voltage $-220 \mathrm{~V}$, the absence of asymmetry $-k=0$, angular velocity $\left.103.149 \mathrm{~s}^{-1}\right)$, the calculated nominal moment $M_{n}=M(220.0,103.149)=1549 \mathrm{Nm}$ corresponds to the 
rated moment of this electric motor according to the passport data equal to $1551 \mathrm{Nm}$. This is one of the evidences of the adequacy of the obtained mathematical model of the electric motor.

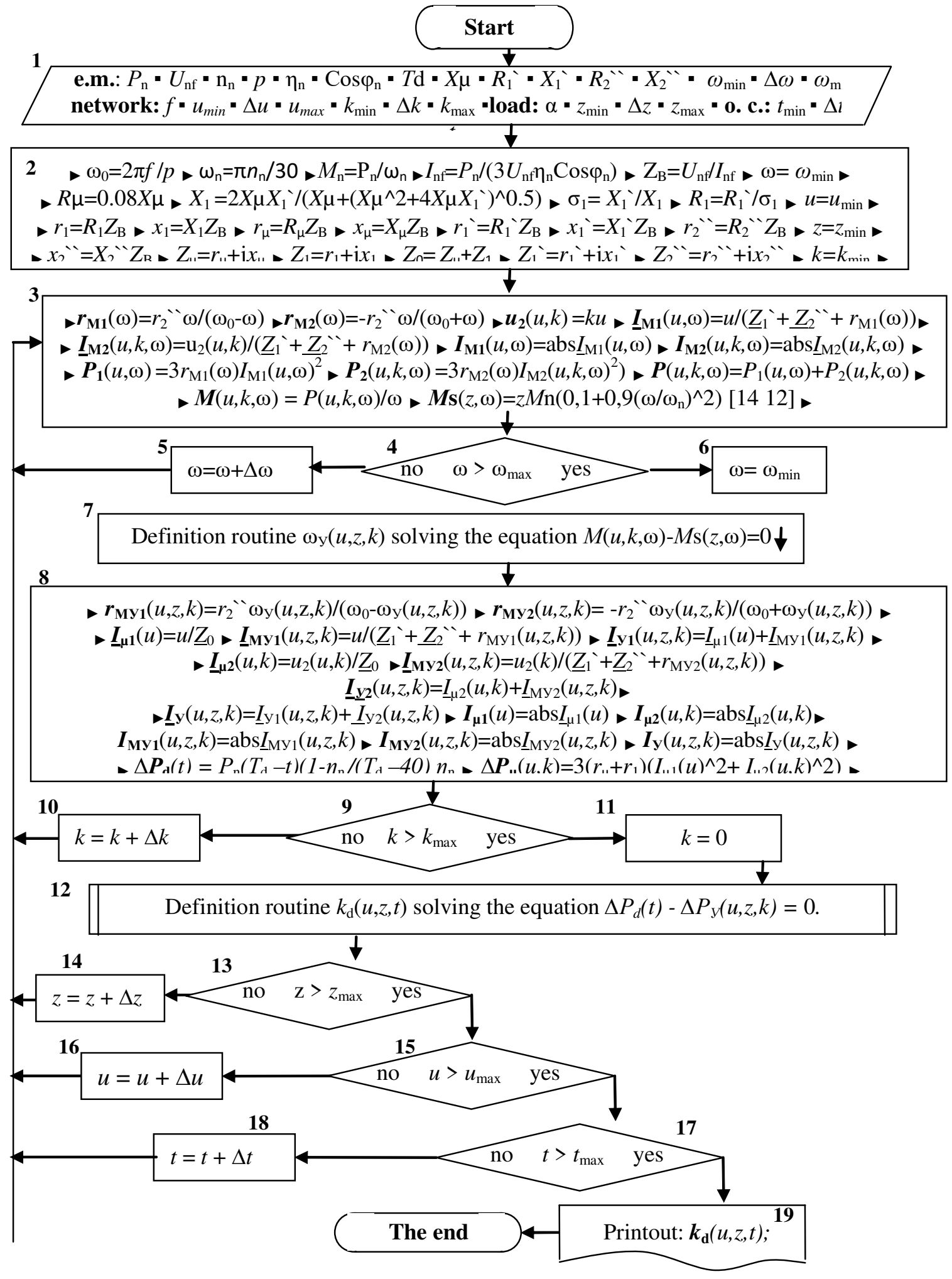

Fig. 3. Algorithm for calculating the allowable asymmetry coefficient in non-nominal operating conditions 


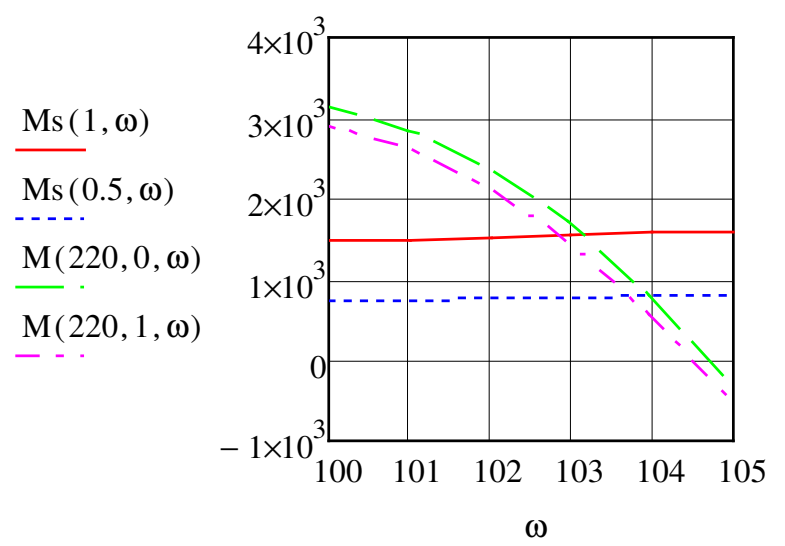

Fig. 4. Mechanical characteristics of the working machine $M_{s}(z, \omega)$ and the electric motor $M(u, k, \omega)$

2. Dependences of the steady-state angular velocity on the degree of asymmetry of the mains voltage for different degrees of load (Fig. $5 a$ ) and different values of the mains voltage (Fig. $5 b$ ).
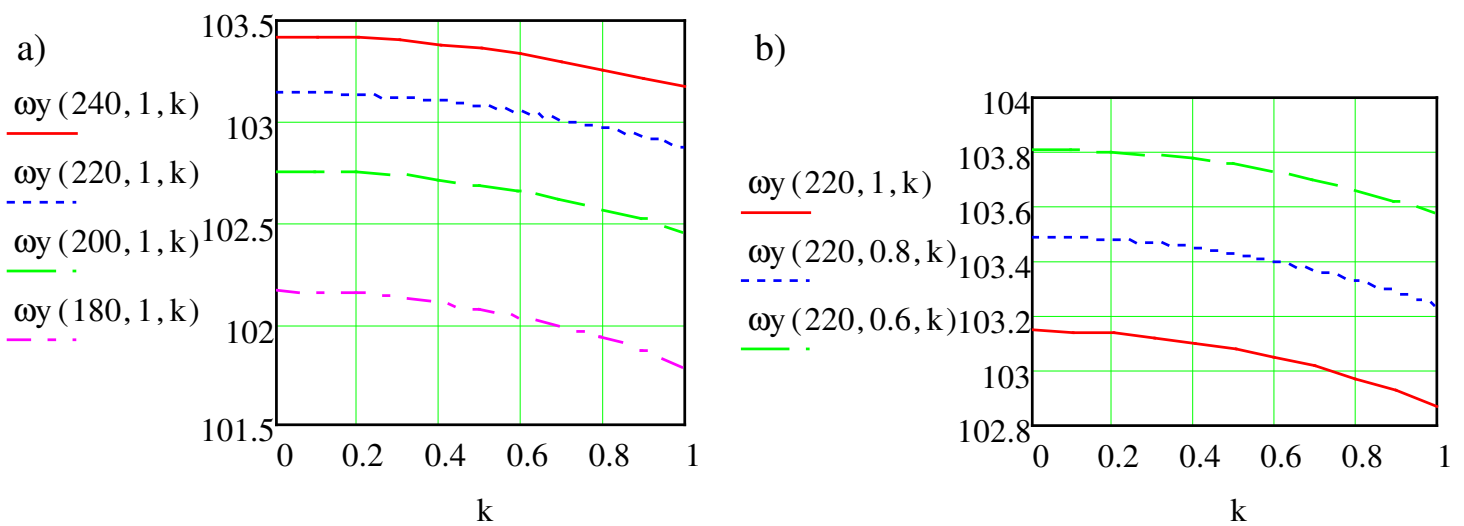

Fig. 5. Dependences of the steady-state angular velocity $\omega_{\mathrm{y}}(u, z, k)$ on the voltage asymmetry coefficient: $\mathrm{a}$ - at a voltage of $220 \mathrm{~V}$ and load factors $1,0.8$, and 0.6 ; b - with an asymmetry coefficient of 1 and a voltage of 180, 200, 220, $240 \mathrm{~V}$

The dependency graphs presented in the figures clearly show that an increase in the degree of asymmetry at any voltage and load degree leads to a decrease in the steady-state angular speed of the electric motor. At the same time, over the entire range of variation of the asymmetry coefficient, the decrease in the steady-state angular velocity will be greater, the greater the deviation of the voltage from the nominal and the greater the degree of load of the electric motor, which is consistent with the logical idea of the nature of these dependencies.

3. Dependences of the power of losses on the degree of asymmetry of the mains voltage at various voltage values and the degree of load of the electric motor. Some of them are shown in Figure 6. In all cases (with varying degrees of load), there is a sharp increase in power losses with an increase in the degree of asymmetry. At the same time, losses for the same values of the asymmetry coefficient increase with increasing degree of electric motor loading. The program allows to determine the power loss for any specific mode of a given electric motor. For example, at a voltage of $200 \mathrm{~V}$, an asymmetry coefficient of 0.04 and a load degree of 0.8 , the power loss in the steady state $\Delta P_{y}$ $(200,0.8,0.04)=9303 \mathrm{~W}$. For the nominal mode, the calculated value of the power loss $\Delta P_{n y}$ $(220,1,0)=11450 \mathrm{~W}$, which fully corresponds to the power loss according to the passport data of the electric motor, equal to $11120 \mathrm{~W}$. The discrepancy does not exceed $3 \%$.

The final calculation result is the allowable asymmetry coefficient as a function of direct sequence voltage, load degree and ambient temperature $k_{d}(u, z, t)$. The program compiled according to the above algorithm allows determining for any specific combination of independent variables. For example, at a voltage of $200 \mathrm{~V}$, a degree of load of 0.9 , and an ambient temperature of $15^{\circ} \mathrm{C}$, 
$k_{d}(200,0.9,15)=0.192$. For the nominal mode, $k_{d}(220,1,40)=0$, which is quite justified, since even a slight voltage asymmetry will lead to overheating of the motor insulation above the permissible temperature for the laid insulation class.

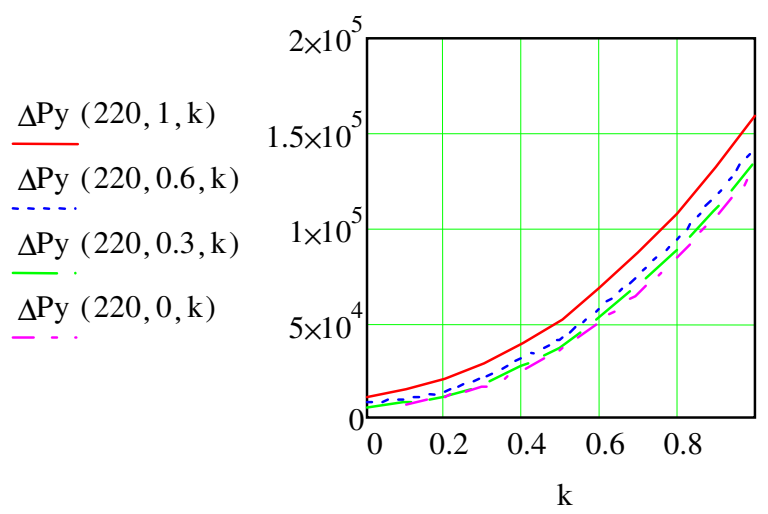

Fig. 6. Dependence of power losses in the steady state $\Delta \boldsymbol{P}_{y}(u, z, k)$ on the asymmetry coefficient at the rated voltage and load factors: $1 ; 0.6 ; 0.3$; and idling

However, a more clear idea of the effect of voltage, load factor, and ambient temperature on the permissible asymmetry coefficient is given by calculating the graphs of the dependence of this coefficient on the listed independent variables of the motor operation mode. Some of the graphs are shown in Figures $7 a$ and $7 b$.

a)

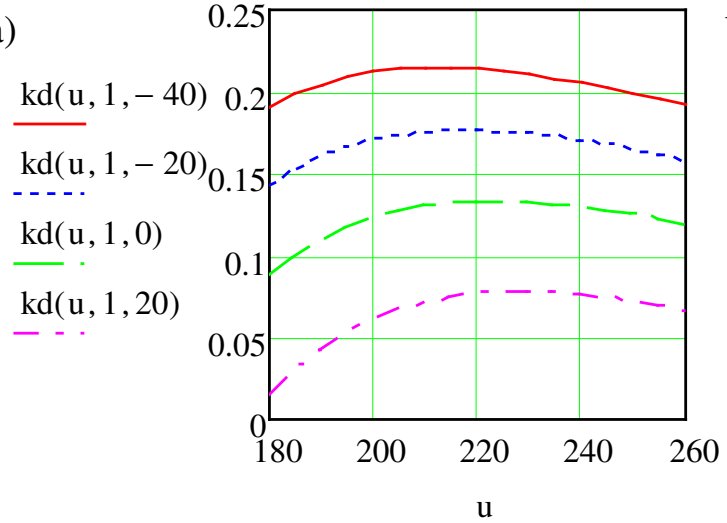

b)

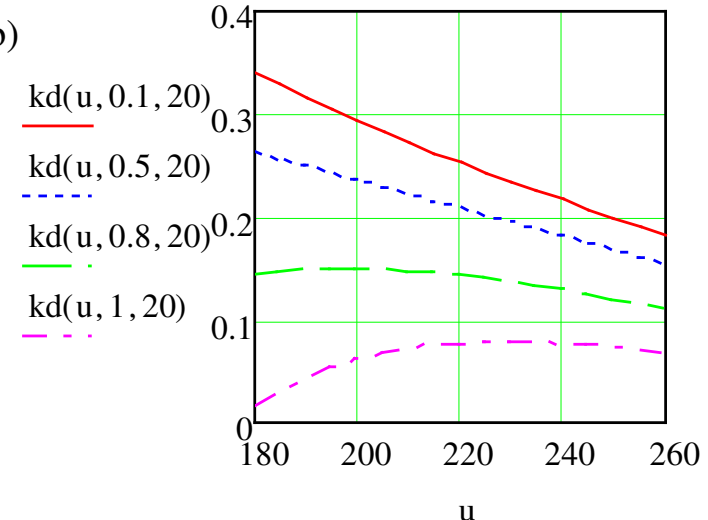

Fig. 7. Dependences of the permissible asymmetry coefficient in the steady state on the voltage of the direct phase sequence: $\mathrm{a}$ - with the load factor of the electric motor equal to 1 and ambient temperatures $-40,-20,0,20^{\circ} \mathrm{C} ; \mathrm{b}-$ at an ambient temperature of $20^{\circ} \mathrm{C}$ and motor load factors $0.1,0.5,0.8,1$

With the rated load of the electric motor (Fig. 7a), the permissible asymmetry coefficient is higher, the lower the ambient temperature, and at all temperatures it reaches a maximum in the voltage range from 200 to 240 volts. A different character of the dependence of the allowable voltage asymmetry coefficient on the voltage of the direct phase sequence is observed at variable load (Fig. $7 b$ ). It strongly depends on the load factor of the electric motor at a voltage below the nominal, sharply increasing when the electric motor is underloaded. At the same time, with increased voltage, when constant power losses begin to dominate, an increase in the allowable asymmetry coefficient and its dependence on the degree of electric motor load decrease.

\section{Conclusions}

Thus, the proposed methodology and algorithm for calculating the operational parameters of any particular asynchronous electric motor operating on a working machine with a known type and parameters of the mechanical characteristics in specific operating conditions allow to determine in stages: 
- steady-state angular velocity as a function of voltage of a direct phase sequence, degree of electric motor load and voltage asymmetry;

- $\quad$ power heat loss in steady state;

- permissible level of voltage asymmetry.

So, for the considered electric motor, which is powered from a network with a voltage variation range from 200 to 240 volts, operating, for example, at an ambient temperature of $20^{\circ} \mathrm{C}$ and a load degree of 0.6 , the permissible asymmetry coefficient is: $k_{d 1}(200,0.6,20)=0.213$ and $k_{d 2}$ ( $240,0.6,20)=0.167$. The smaller of these values must be guided in determining the setting of protection against voltage asymmetry.

\section{References}

[1] Данилов И.Н. Защита электродвигателей от аварийных режимов работы (Protection of electric motors from emergency operation) // Техника в сельском хозяйстве (Agricultural machinery). - 1988. - No.2. - pp. 19-22. (In Russian).

[2] Соркинд М. Асинхронные электродвигатели 0,4 кВ (Asynchronous electric motors 0,4). Аварийные режимы работы. ООО "Новатек-Электро" (Emergency operating modes LLC Novatek-Electro). St. Petersburg. http://nevs.elteh.ru/arh2005/32/15php. (In Russian)

[3] Мартыненко И.И. Допустимая мощность электродвигателей при асимметрии напряжений (Permissible motor power with voltage asymmetry). Механизация и электрификация социалистического сельского хозяйства (The mechanization and electrification of socialist agriculture). - 1957. - No.4. - pp. 21-23. (In Russian).

[4] Куренный Э.Г., Дмитриева Е.Д., Лютый А.П., Сидоренко О.А.. Оценка и нормирование несимметрии напряжений в системах электроснабжения общего назначения (Assessment and Standardization of Voltage Unbalance in General-Purpose Power Supply Systems). Электричество. Национальный исследовательский университет "МЭИ” (Москва). (Electricity. National Research University MPEI (Moscow)). - No.4. - 2008. - pp. 18-27. (In Russian).

[5] Novozhilov N.G. Digital algorithm for fast detecting and identifying the asymmetry of voltages in three-phase electric grids of mechanical engineering facilities / N.G. Novozhilov, O.B. Shonin, S.B. Kryltcov // IOP: Materials Science and Engineering. - 2017. - V.177. - pp. 253-258.

[6] М.П. Костенко, Л.М. Пиотровский. Электрические машины, часть II (Electric cars, part II). Госэнергоиздат, Москва-Ленинград (Electric cars, part II. Gosenergoizdat, MoscowLeningrad), 1958. - 29 p. (In Russian).

[7] Колесов Л.В., Карпов В.Н., Косоухов Ф.Д., Меркучев Д.А., Цупак А.В. Электрооборудование и автоматизация сельскохозяйственных агрегатов и электроустановок (Electrical equipment and automation of agricultural units and electrical installations). „Колос” (Ленингр. отд-ние) („Kolos” Leningrad department). - 1974. - pp. 255258. (In Russian).

[8] Петько В.Г. А.с. 1069056. Устройство для защиты электроустановки от неправильного чередования фаз и асимметрии фазных напряжений (Device for protecting electrical installations from incorrect phase rotation and phase voltage asymmetry). Заявитель и патентообладатель - ФГОУ ВПО ОГАУ (Applicant and patent holder Orenburg State Agrarian University); published. 23.01.84. - No.3. - pp. 1-4. (In Russian).

[9] Петько В.Г., Садчиков А.В. Патент 2220488 С2. Российская Федерация. Устройство для защиты трехфазного электродвигателя от асимметрии питающего напряжения [Текст] (Device for protecting three-phase motor against supply voltage unbalance); Заявитель и патентообладатель - ФГОУ ВПО ОГАУ (Applicant and patent holder Orenburg State Agrarian University). 27.06.2003. - pp. 1-4. (In Russian).

[10]Петько В.Г., Рахимжанова И.А. Устройство защиты электроприводов сельскохозяйственного назначения от асимметрии напряжения (The device for protection of agricultural electric drivers against voltage asymmetry). Известия Оренбургского ГАУ (Izvestia Orenburg State Agrarian University). - 2017. - No.2. - pp. 88-92. (In Russian).

[11] Петров А.С., Петько В.Г., Шахов В.А., Асманкин Е.М., Ушаков Ю.А. Режимные параметры асинхронного электродвигателя при асимметрии напряжения (Mode Parameters of an 
Asynchronous Motor with Voltage Asymmetry). Достижения науки и техники АПК (Achievements of science and technology of agribusiness). - 2017. - T 31. No.8. - pp. 68-73. (In Russian).

[12]Петько В.Г., Петров А.С. Параметры установившегося режима асинхронного электродвигателя при асимметрии питающего напряжения в сельской электрической сети (Parameters of the established regime of the asynchronous electric motor with the asymmetry of the supply voltage in the rural electric grid). Известия Оренбургского ГАУ (Izvestia Orenburg State Agrarian University). - 2018. - No.72. - pp. 218-222. (In Russian).

[13]Ключев В.И. Теория электропривода: Учеб. для вузов. - 2-е изд. перераб. и доп. (Theory electric drive) - М.: Энергоатомиздат (M.: Energoatomizdat). - 2001. - 704 p. (In Russian)

[14]Г.И. Назаров, Н.П. Олейник, А.П. Фоменков, И.М. Юровский. Электропривод и применение электрической энергии в сельском хозяйстве. Издание 2-е переработанное и дополненное (Electric drive and application of electric energy in agriculture 2nd Edition). Москва, "КОЛОС" (Moscow “KOLOS"). - 1972. - pp. 18-19. (In Russian).

[15] А.Э. Кравчик, М.М. Шлаф, В.И. Афонин, Е.А. Соболенская. Асинхронные двигатели 4Ф: Справочник (Asynchronous Motors: Reference). - М.. Энергоиздат, (M. Energoatomizdat). 1982. - P.504. (In Russian).

[16] А.А. Бойко, В.В. Будашко, Е.А. Юшков, Н.А. Бойко. Синтез и исследование системы автоматического симметрирования токов асинхронного двигателя с преобразователем напряжения (Synthesis and study of a system for automatically balancing currents of an induction motor with a voltage converter). Восточно-Европейский журнал передовых технологий (East European Journal of Advanced Technology). - 2016. Т. 1. - No. 2 (79). pp. 2234. (In Russian). 